\title{
ANALISIS SWOT SEBAGAI DASAR KEPUTUSAN STRATEGI PEMASARAN PADA PERUSAHAAN SERVER PULSA DI KOTA BATAM (STUDI KASUS PADA CV. STAR PRATAMA)
}

\author{
Rahmat Hidayat ${ }^{1)}$, Ricky Rahmat ${ }^{2)}$ \\ 1) Prodi Administrasi Bisnis Terapan Politeknik Negeri Batam, email: rahmat@polibtam.ac.id \\ 2) Prodi Administrasi Bisnis Terapan Politeknik Negeri Batam, email: riickyrahmat@gmail.com
}

\begin{abstract}
This study aims to determine the factors that become the strengths and weaknesses, the factors that become challenges and threats, knowing how the position of CV STAR PRATAMA server business compared with other server business and strategy that must be applied by the CV STAR PRATAMA server business. From the results of the study using SWOT analysis shows that based on the SWOT diagram, CV STAR PRATAMA has a position in quadrant I. In this quadrant is very profitable, based on the Matrix IE (Internal-External Matrix) then CV STAR PRATAMA is on the cell and analysis results In the final stage of using QSPM, it can be seen that the current strategy is one of the ST (Strength-Threat) strategy that is by improving the excellent service and after sales service to satisfy the customer.
\end{abstract}

Keywords: SWOT Analysis, IE Matrix, Marketing Strategy

abstrak

Penelitian ini bertujuan untuk mengetahui faktor-faktor yang menjadi kekuatan dan kelemahan, faktor-faktor yang menjadi peluang dan ancaman, mengetahui bagaimana posisi bisnis server pulsa CV STAR PRATAMA dibandingkan dengan bisnis server pulsa lainnya serta strategi yang harus diterapkan oleh bisnis server pulsa CV STAR PRATAMA. Dari hasil penelitian menggunakan analisa SWOT menunjukkan bahwa berdasarkan diagram SWOT, CV STAR PRATAMA memiliki posisi pada kuadran I. Pada kuadran ini situasi perusahaan sangat menguntungkan, berdasarkan Matrik IE (Matrik Internal-Eksternal) maka CV STAR PRATAMA berada pada sel V dan berdasarkan hasil analisis pada tahap keputusan menggunakan QSPM, dapat dilihat bahwa strategi yang terbaik yang harus dilakukan saat ini adalah salah satu strategi ST (Strength-Threat) yaitu dengan meningkatkan pelayanan prima serta layanan purna jual demi memuaskan pelanggan.

Kata kunci: Analisa SWOT, Matrik IE, Strategi Pemasaran 


\section{PENDAHULUAN}

Generasi saat ini memiliki banyak keunggulan dengan perkembangan teknologi yang begitu cepat. Teknologi sangat diperlukan untuk mempermudah dan memaksimalkan suatu kinerja. Salah satu teknologi yang memiliki perkembangan yang cukup cepat ialah telepon seluler. Perangkat mobile ini digunakan untuk memudahkan komunikasi jarak jauh bagi pengguna yang mempunyai mobilitas tinggi. Karena dengan menggunakan perangkat mobile ini, komunikasi tidak lagi terikat dengan jarak dan kabel. Perkembangan pesat dalam dunia komunikasi tentunya akan mengubah pola komunikasi yang terjadi di masyarakat selama ini (Hamidin, 2009).

Perangkat mobile disebagian masyarakat sudah menjadi kebutuhan bagi semua kalangan, baik itu kalangan bawah, menengah, maupun atas. Perkembangan teknologi mobile sudah mengalami kemajuan yang cukup signifikan. Mulai dari sebagai sarana komunikasi (telepon \& pesan singkat) hingga menjadi sarana alat bertransaksi keuangan, Global Positioning System (GPS), $M$ banking, M-commerce, social network, dan aplikasi yang lainya. Dengan kehadiran teknologi jaringan seperti 3G, 4G, HSDPA, wireless, dan bluetooth proses transfer data menjadi semakin cepat (Yuniansyah, 2011).

Perangkat mobile saat ini tidak lagi hanya digunakan untuk menelepon dan mengirim pesan, tetapi juga dapat digunakan untuk mengirim gambar, chatting maupun browsing, hingga untuk fasilitas video call. Dengan kemajuan teknologi

telepon selular dan layanan yang disediakan, menyebabkan telepon selular hampir menyamai fasilitas komputer personal.

Kebutuhan masyarakat akan komunikasi semakin hari semakin meningkat, khususnya di Negara Indonesia. Peraturan pemakaian sarana komunikasi jarak jauh, diatur dan diserahkan ke masing-masing provider penyedia jalur komunikasi. Pengguna produk jalur komunikasi bisa mendapatkan produk tersebut dengan dengan cara pembayaran didepan (Pra-bayar) atau pembayaran di belakang setelah pemakaian (Pasca-bayar). Untuk pemakaian Pra-bayar, biaya komunikasi akan dikalkulasikan pada pulsa telepon yang telah dibeli sebelumnya. Pulsa telepon nantinya akan dipotong langsung sesuai dengan biaya dan regulasi yang diterapkan provider komunikasi.

Pulsa telepon bisa didapatkan dengan cara membeli langsung berupa pulsa kartu (voucher) atau berupa pulsa elektrik. Kalangan masyarakat saat ini cenderung menggunakan pembelian pulsa elektrik daripada pulsa kartu (voucher). Hematnya waktu pembelian dan mudahnya proses pengisian pulsa telepon, menjadi bahan pertimbangan masyarakat untuk memilih pengisian pulsa elektrik. Pengisian pulsa telepon elektrik dilakukan oleh beberapa agen atau pedagang eceran pulsa, dimana seorang agen atau pengecer pulsa akan membeli nominal deposit pulsa di suatu perusahaan server pulsa.

Menurut https://support.voucha.co.id, ada 2 macam jalur saluran distribusi pulsa yaitu:

1. Modern Channel, yaitu saluran distribusi pulsa Non-Dealer seperti bank, convenience store, dan bisnis utamanya yang bukan mendistribusikan produk dari operator.

2. Traditional Channel, yaitu saluran disribusi pulsa yang bisnis utamanya memang mendistribusikan produk dari operator. Pihak tersebut adalah seperti mitra AD (Authorized Dealer) dan Agen.

3. Tahapan jalur saluran distibusi pulsa melalui traditional channel,yaitu:

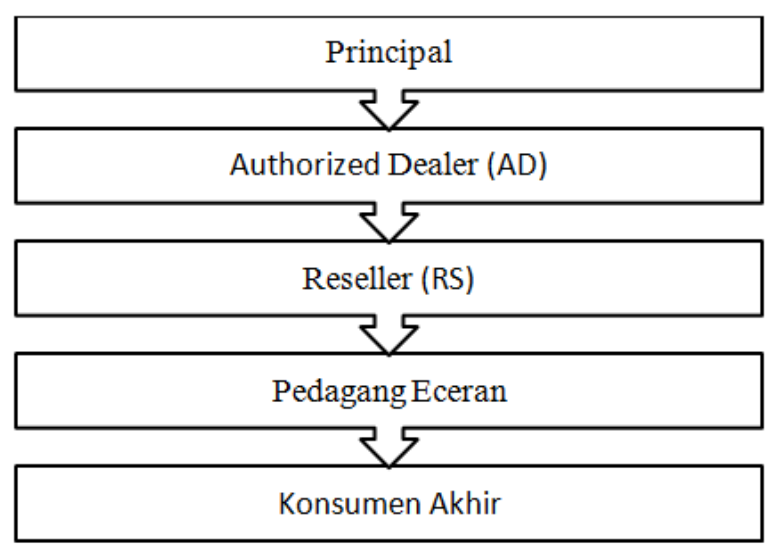

Gambar 1 Struktur jalur distribusi pulsa secara Traditional Channel

Sumber: https://support.voucha.co.id

a. Principal adalah perusahaan yang memiliki produk dan bekerja sama dengan perusahaan lain untuk mendistribusikan produknya. Dalam hal ini, principal adalah operator itu sendiri. 
Rahmat \& Ricky, analisis swot sebagai dasar keputusan strategi pemasaran ....

b. Authorized Dealer (AD) adalah mitra yang langsung berhubungan dengan operator. $\mathrm{AD}$ bertugas untuk mendistribusikan produk dari principal di wilayah tertentu dan dengan jumlah tertentu. AD melakukan deposit ke principal sebagai jaminan dari alokasi yang diberikan tiap minggunya. Jumlah alokasi per-minggu ditentukan oleh principal berdasarkan market capacity dari wilayah tertentu. AD mendistribusikan alokasi yang sudah diberikan kepada mitra Reseller atau Agen Reseller (RS).

c. Reseller (RS) mengambil alokasi recharge dan membayar sejumlah deposit melalui AD. Deposit ini tersimpan dalam sistem milik operator. Pada saat RS melakukan order (pembelian alokasi), AD mengirim pesan ke sistem milik operator dan operator mengirimkan order tersebut kepada RS. Setelah RS mendapatkan alokasi dalam bentuk saldo maupun unit, maka RS dapat melakukan pengisian kepada konsumen.

d. Pedagang eceran adalah pedagang yang membeli barang dari Reseller (server) kemudian menjualnya langsung ke konsumen akhir.

Perusahaan server pulsa sebenarnya masuk dalam kategori Reseller (RS) yang membeli stock pulsa dari Authorized Dealer (AD) dan menjualnya ke pedagang eceran. Perusahaan server pulsa merupakan perusahaan penyedia perangkat server pulsa dan software penjualan pulsa elektrik. Dalam jalur distribusi pulsa, umumnya mereka mengambil pulsa dari para dealer operator dan mendistribusikan kepada agen-agen. Satu pengusaha server pulsa bisa melayani sekitar 20 ribu agen pengecer pulsa (http://techno.okezone.com)

Bisnis server isi ulang pulsa adalah bisnis yang bergerak dalam perdagangan dan pendistribusian pulsa dari berbagai provider. Disini posisi dari server pulsa adalah sebagai grosir yang membawahi outlet dan termasuk dalam jalur distribusi pulsa Traditional Channel.

Salah satu perusahaan server pulsa di Kota Batam adalah CV STAR PRATAMA. Perusahaan ini beralamat di Komplek Ruko Fanindo Blok F no.11 Tanjung Uncang, Batam
Indonesia. Perusahaan ini bergerak di bidang perdagangan tepatnya di bagian pendistribusian pulsa elektrik maupun pulsa fisik. Perusahaan ini didirikan pada bulan Juli 2010 terdaftar di Rektorat Jendral pajak nomor: PEM5052/WPJ.02/KP.1303/2010 dengan izin usaha nomor: $\quad$ 0815/perindag-BTM/PK/VII/2010 sebagai penanggung jawab YULI HENDRI, ST.

Perusahaan server pulsa memiki omzet yang cukup menggiurkan. Seorang pengusaha server pulsa bisa mencatat transaksi hingga 500.000 per hari. Jika diasumsikan pulsa Rp10.000 per transaksi, dan mencatat 3.000 transaksi saja dalam sehari, pemilik tersebut dapat mencetak omzet Rp900 juta hingga Rp1 miliar per bulannya (http://teknologi.news.viva.co.id)

Tetapi semakin berkembangnya zaman, masyarakat sudah disuguhkan kemudahan dalam membeli pulsa. Dengan adanya jalur distribusi pulsa modern channel, pulsa dapat dibeli melalui Mesin ATM (Anjungan Tunai Mandiri), Internet-banking, Mobile-Banking, SMS-Banking, Carrefour, Hypermart, Alfamart ataupun Indomaret.

Mengutip dari artikel yang dimuat pada http://teknologi.news.viva.co.id, pengisian ulang pulsa melalui modern channel akan berkembang pesat kedepannya. Walaupun saat ini pengisian ulang pulsa melalui modern channel hanya $20 \%$, tetapi dalam kurun waktu tiga tahun, saluran ini bisa meningkat menjadi 40\%. Hal ini dipengaruhi oleh perubahan perilaku pada masyarakat yang mulai menggunakan saluran modern dan serba ingin cepat.

Tentu dengan maraknya penggunaan modern channel, perusahaan server pulsa yang tentunya adalah saluran tradisional mendapatkan ancaman dan tantangan yang berat kedepannya. Persaingan yang ketat, peningkatan inflasi, pertumbuhan ekonomi, dan perubahan teknologi mengharuskan perusahaan server pulsa memiliki analisis strategi untuk mengantisipasi persaingan di kemudian hari.

Sebagai bisnis yang memiliki potensi menjanjikan, bisnis server pulsa inipun harus memiliki strategi untuk bisa memenangkan pasar khususnya di Kota Batam. Oleh karena itu penulis tertarik ingin meneliti strategi perusahaan untuk memaksimalkan potensipotensi tersebut. Maka dari itu penulis 
mengangkat judul, "Analisis SWOT Sebagai Dasar Keputusan Strategi Pemasaran pada Perusahaan Server Pulsa di Kota Batam (Studi Kasus pada CV. Star Pratama)".

\section{Rumusan Masalah}

Berdasarkan latar belakang yang telah dikemukakan di atas maka dalam penelitian ini dirumuskan masalah sebagai berikut:

1. Apakah faktor-faktor yang menjadi kekuatan dan kelemahan bisnis server pulsa CV. Star Pratama.

2. Apakah faktor-faktor yang menjadi peluang dan ancaman bagi bisnis server pulsa CV. Star Pratama.

3. Bagaimana posisi bisnis server pulsa $\mathrm{CV}$ STAR PRATAMA dibandingkan dengan bisnis server pulsa lainnya.

4. Apakah strategi yang harus diterapkan oleh bisnis server pulsa CV STAR PRATAMA.

\section{Tujuan Penelitian}

1. Mengetahui apakah faktor-faktor yang menjadi kekuatan dan kelemahan bisnis server pulsa CV. Star Pratama.

2. Mengetahui apakah faktor-faktor yang menjadi peluang dan ancaman bagi bisnis server pulsa CV. Star Pratama.

3. Mengetahui bagaimana posisi bisnis server pulsa CV STAR PRATAMA dibandingkan dengan bisnis server pulsa lainnya

4. Mengetahui apakah strategi yang harus diterapkan oleh bisnis server pulsa CV STAR PRATAMA.

\section{Manfaat Penelitian}

Dengan dilaksanakannya penelitian ini, diharapkan dapat memberi manfaat yang luas antara lain:

1. Manfaat Praktis

Sebagai masukan kepada Manajemen Perusahaan dalam upaya meningkatkan potensi usaha server pulsa. Diharapkan hasil penelitian ini dapat memperkaya referensi untuk pengembangan ilmu pengetahuan khususnya ilmu pemasaran.

2. Manfaat Teoritis

a. Bagi Penulis

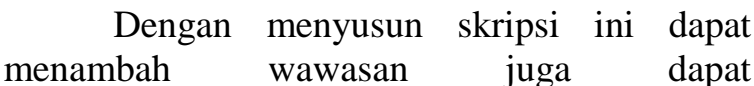
mengaplikasikan ilmu yang didapat selama perkuliahan khususnya pada mata kuliah Pemasaran. Hasil penilitian ini memberikan informasi bagi penulis tentang bagaimana permasalah-permasalahan di usaha server pulsa.

b. Bagi Pembaca

Sebagai referensi dan masukan bagi pembaca dimasa yang akan datang dalam mengkaji masalah serta dapat dijadikan acuan atau referensi untuk topik yang serupa.

\section{Konsep Strategi}

Strategi adalah tujuan jangka panjang dari suatu perusahaan, serta rumusan pada pendayagunaan dan semua alokasi sumber daya yang penting untuk mencapai tujuan tersebut (Rangkuti, 2009).Menurut Rahayu (2015), strategi merupakan cara untuk mencapai tujuan jangka pajang. Strategi bisnis bisa berupa perluasan geografis, diversifikasi, akuisisi, pembangunan produk, penetrasi pasar, rasionalisasi karyawan, divestasi, likuidasi, dan joint venture.

Secara umum, strategi dapat diartikan sebagai " sekumpulan pilihan kritis untuk perencanaan dan penerapan serangkaian rencana tindakan dan alokasi sumber daya yang penting dalam mencapai tujuan dan sasaran, dengan memperhatikan keunggulan kompetitif, komparatif, dan sinergis ideal berkelanjutan kearah, cakupan dan perpektif jangka panjang keseluruhan yang ideal dari individu atau organisasi”.

\section{Manajemen Strategis}

Manajemen strategis adalah seni dan ilmu untuk pembuatan (formulating), penerapan (implementing) dan evaluasi (evaluating) keputusan-keputusan strategis antar fungsi yang memungkinkan sebuah perusahaan mencapai tujuan di masa yang akan datang (Umar, 2001). Namun untuk saat ini konsep strategi mengalami perkembangan, menurut (Andrew dan Chaffe diacu dalam Umar 2001), strategi merupakan kekuatan motivasi untuk stakeholder baik secaralangsung maupun tidak langsung menerima keuntungan atau biaya yang ditimbulkan oleh semua tindakan yang dilakukan. Proses manajemen strategis berusaha mengorganisasikan informasi kuantitatif dengan 
Rahmat \& Ricky, analisis swot sebagai dasar keputusan strategi pemasaran ....

cara yang memungkinkan keputusan efektif diambil dalam kondisi tidak menentu.

Menurut David (2009), manajemen strategis merupakan seni dan pengetahuan untuk menformulasikan, mengimplementasikan, dan mengevaluasi keputusan lintas fungsional yang membuat organisasi mampu mencapai tujuannya. Manajemen strategis akan membantu perusahaan dalam melihat ancaman dan peluang di masa yang akan datang, sehingga memungkinkan organisasi untuk dapat mengantisipasi kondisi yang selalu berubah. Selain itu, manajemen strategis juga menyediakan sasaran serta arah yang jelas bagi masa depan perusahaan, sehingga perusahaan yang mengembangkan sistem manajemen strategis mempunyai kemungkinan tingkat keberhasilan lebih besar daripada yang tidak menggunakan sistem ini.

Jadi, inti dari manajemen strategis adalah untuk mengidentifikasi tujuan organisasi, bagaimana menggunakan sumber daya secara efektif untuk memenuhi tujuan strategis. Manajemen strategis harus memberikan fondasi dasar atau pedoman untuk pengambilan keputusan dalam organisasi.

\section{Definisi Pemasaran}

Pemasaran sangat memegang peran penting dalam daur produk dari produsen ke tangan konsumen. Menurut Kotler (2008), definisi pemasaran dibedakan menurut sosial dan manajerial. Definisi sosial menunjukkan peran yang dimainkan oleh pemasaran didalam masyarakat, yaitu "menghasilkan standar hidup yang lebih tinggi". Sedangkan definisi manajerial, yaitu pemasaran digambarkan sebagai "seni menjual produk". Jadi pemasaran adalah suatu proses sosial yang didalamnya individu dan kelompok mendapatkan apa yang mereka butuhkan dan inginkan dengan menciptakan, menawarkan, dan secara bebas menukarkan produk yang bernilai dengan pihak lain.

Definisi pemasaran dalam Rangkuti (2009), Pemasaran adalah suatu proses kegiatan yang dipengaruhi oleh berbagai faktor sosial, budaya, politik, ekonomi dan manajerial. Akibat dari berbagai faktor tersebut masing-masing individu maupun kelompok mendapatkan kebutuhan dan keinginan dengan menciptakan, menawarkan, dan menukarkan produk yang memiliki nilai komoditas.

Sehingga dapat diambil kesimpulan bahwa, pemasaran adalah metode yang digunakan sebuah perusahaan dalam mengenalkan sebuah barang/jasa dengan cara merencanakan, menetukan harga, mempromosikan, menawarkan dan mendistribusikan barang/jasa tersebut sehingga dapat memenuhi kebutuhan pembeli.

\section{Strategi Pemasaran}

Strategi pemasaran dalam bisnis merupakan suatu cara untuk memperoleh hasil yang diinginkan berdasarkan kondisi dan struktur yang berlaku. Strategi ini berguna untuk mengantisipasi masalah-masalah dan kesempatan masa depan dalam kondisi yang tepat secara sistematis, rasional, kritis, komprehensif dan integrative (Ahmad, 2013). Strategi pemasaran mengartikulasikan sebuah rencana dalam penggunaan terbaik sumber daya dan keunggulan perusahaan untuk mencapai tujuannya.

Sedangkan menurut Kotler dan Amstrong (2003), strategi pemasaran adalah proses merangkum pola pikir pemasaran secara umum yang ingin digunakan oleh unit bisnis untuk mencapai tujuan pemasaran dan secara lebih spesifik menyatakan pasar yang akan dibidik, penetapan posisi dan tingkatan pengeluaran pemasarannya.

Jadi, bisa disimpulkan pengertian dari strategi pemasaran ialah suatu proses pengambilan keputusan-keputusan tentang biaya pemasaran, bauran pemasaran, alokasi pemasaran dalam hubungan dengan keadaan lingkungan yang diharapkan dan kondisi persaingan.

\section{Unsur Strategi Pemasaran}

Unsur strategi persaingan dalam Rangkuti (2009) dapat dikelompokkan menjadi tiga, yaitu:

\section{Segmentasi Pasar}

Segmentasi pasar adalah tindakan mengidentifikasikan dan membentuk kelompok pembeli atau konsumen secara terpisah. Masingmasing segmen konsumen ini memiliki karakteristik, kebutuhan produk, dan bauran pemasaran tersendiri. 


\section{Target Pasar (Targetting)}

Target pasar adalah suatu tindakan memilih satu atau lebih segmen pasar yang akan dimasuki.

3. Posisi Pasar (Positioning)

Positioning adalah penetapan posisi pasar. Tujuan Positioning ini adalah untuk membangun dan mengkomunikasikan keunggulan bersaing produk yang ada di pasar ke dalam benak konsumen.

\section{Analisis Lingkungan Perusahaan}

Keunggulan yang dicapai suatu perusahaan tergantung bagaimana perushaaan tersebut menganalisis bisnis mereka. Perusahaan menyadari bahwa lingkungan selalu mengalami perubahan. Untuk itu, perusahaan harus mampu beradaptasi terhadap perubahan tersebut, lingkungan bisnis dapat dibagi menjadi dua lingkungan, yaitu lingkungan eksternal dan lingkungan internal.

\section{Analisis Lingkungan Eksternal}

Menurut Porter yang dikutip oleh Umar (2005) Lingkungan eksternal dibagi kedalam dua katagori yaitu lingkungan makro dan lingkungan industri. Penjelasan kedua katagori eksternal yakni sebagai berikut:

1. Lingkungan Makro

Elemen-elemen yang ada dalam lingkungan ini memberikan pengaruh yang tidak langsung pada perusahaan. Elemen-elemen yang perlu diperhatikan adalah sebagai berikut:

a. Elemen Perekonomian.

Perekonomian berkaitan dengan bagaimana orang atau bangsa memproduksi, mendistribusikan, dan mengonsumsi berbagai barang dan jasa.Perusahaan perlu memperhatikan sejauh mana perekonomian dapat mempengaruhi perusahaan/organisasi dari segi upah tenaga kerja, inflasi, perpajakan, pengangguran, dan harga barang yang dikelola.

b. Elemen Politik dan Legal.

Situasi politik, perpolitikan, dan masalah legal sangat terkait dengan keberlangsungan perusahaan untuk jangka panjang. Situasi perpolitikan yang kondusif memberikan kenyamanan bagi para organisasi/pelaku usaha.

c. Elemen Sosial-Budaya.
Kondisi sosial yang dimaksud adalah seperti kondisi demografi, sikap, gaya hidup, adat istiadat, dan kebiasaan dari orang-orang eksternal perusahaan. Begitupula dari kondisi budaya seperti ekologis, demografis, religious, pendidikan dan etnis.

d. Elemen Lingkungan Teknologi.

Ilmu dan pengetahuan manusia terus berkembang dari waktu ke waktu.Ini membuat teknologi juga berkembang pesat. Teknologi tidak hanya mencakup penemuan-penemuan yang baru saja, tetapi juga meliputi caracara pelaksanaanya atau metode-metode baru dalam mengerjakan suatu pekerjaan, artinya teknologi memberikan suatu gambaran yang luas meliputi mendesain, menghasilkan, dan mendistribusikan.

2. Lingkungan Industri.

Aspek lingkungan industri akan lebih mengarah pada aspek persaingan di-mana bisnis perusahaan berada.

a. Ancaman Pelaku Bisnis Baru

Masuknya perusahaan sebagai pendatang baru akan menimbulkan sejumlah implikasi bagi perusahaan yang sudah ada.

b. Ancaman Produk Substitusi

Perusahaan-perusahaan yang berada dalam industri tertentu akan bersaing pula dengan produk pengganti.

c. Kekuatan Tawar-Menawar Pembeli

Pembeli ini biasanya bisa memaksa perusahaan untuk menurunkan harga atau menuntut meningkatkan kualitas produk/jasa, serta mengadu perusahaan dengan kompetitornya.

d. Kekuatan Tawar-Menawar Pemasok

Bila pemasok memiliki daya tawar yang semakin kuat, maka semakin kurang menarik industrinya.

e. Persaingan Dalam Industri

Persaingan dalam industri akan mempengaruhi kebijakan dan kinerja perusahaan. Dalam situasi persaingan yang oligopoly, perusahaan mempunyai kekuatan yang cukup besar untuk mempengaruhi pasar. Sedangkan pada pasar persaingan sempurna 
Rahmat \& Ricky, analisis swot sebagai dasar keputusan strategi pemasaran ....

biasanya akan memaksa perusahaan menjadi follower termasuk dalam hal harga produk.

\section{Analisis Lingkungan Internal}

Secara garis besar, aspek-aspek lingkungan internal perusahaan yang hendaknya diamati dapat dilihat dari beberapa pendekatan, yakni sebagai berikut:

1. Pendekatan Fungsional

$$
\text { Pada pendekatan ini, }
$$

pengkategorian analisis internal sering diarahkan pada pasar dan pemasaran, kondisi keuangan dan akunting, produksi, sumber daya manusia, dan struktur organisasi dan manajemen.

2. Pendekatan Rantai Nilai (Value Chains)

Analisis dengan pendekatan Rantai Nilai didasarkan pada serangkaian kegiatan yang berurutan dari sekumpulan aktivitas nilai (value activities) yang dilaksanakan untuk mendesain, memproduksi, memasarkan, mengirimkan, serta mendukung produk dan jasa mereka pada perusahaan yang terdiri dari satu SBU saja.

\section{Matriks IFE dan Matriks EFE}

Matriks IFE dan EFE terdiri dari kolom bobot, rating, dan total nilai yang merupakan hasil kali dari bobot dan rating. Untuk kolom bobot dan rating diisi sesuai dengan nilainya yang merupakan hasil dari pengelompokan faktor-faktor internal dan eksternal berdasarkan tingkat kepentingannya.

Menurut David (2009), menyatakan bahwa matriks IFE digunakan untuk mengetahui faktor-faktor internal perusahaan yang berkaitan dengan kekuatan dan kelemahan yang dihadapi perusahaan terdiri dari aspek sumber daya manusia, pemasaran, produksi dan operasi, keuangan dan akuntasi dan sistem informasi. Matriks EFE digunakan untuk mengevaluasi faktor-faktor eksternal perusahaan. Data eksternal dikumpulkan untuk menganalisis halhal menyangkut persoalan ekonomi, politik dan pemerintahan, sosial budaya, teknologi, lingkungan, demografi, persaingan di pasar industri dimana perusahaan berada, serta data eksternal relevan lainnya. Hal ini penting karena faktor eksternal perusahaan berpengaruh langsung maupun tidak langsung terhadap perusahaan.

\subsubsection{Analisis SWOT}

Analisis SWOT adalah identifikasi berbagai faktor secara sistematis untuk merumuskan strategi perusahaan (Rangkuti, 2009). Matriks SWOT merupakan matching tool yang penting untuk membantu mengembangkan empat tipe strategi yaitu sebagai berikut:

a. Strategi SO (Strength-Opportunity), strategi menggunakan kekuatan internal perusahaan untuk meraih peluang-peluang yang ada di luar perusahaan.

b. Strategi WO (Weakness-Opportunity), strategi ini bertujuan untuk memperkecil kelemahan-kelemahan internal perusahaan dengan memanfaatkan peluang-peluang perusahaan.

c. Strategi ST (Strength-Threat), melalui strategi ini perusahaan berusaha untuk menghindari atau mengurangi dampak dari ancaman-ancaman eksternal.

Strategi WT (Weakness-Threat), strategi ini merupakan taknik untuk bertahan dengan cara mengurangi kelemahan internal serta menghindari ancaman

\section{Kerangka Pemikiran}

Kerangka pemikiran yang penulis rancang adalah sebagai berikut :

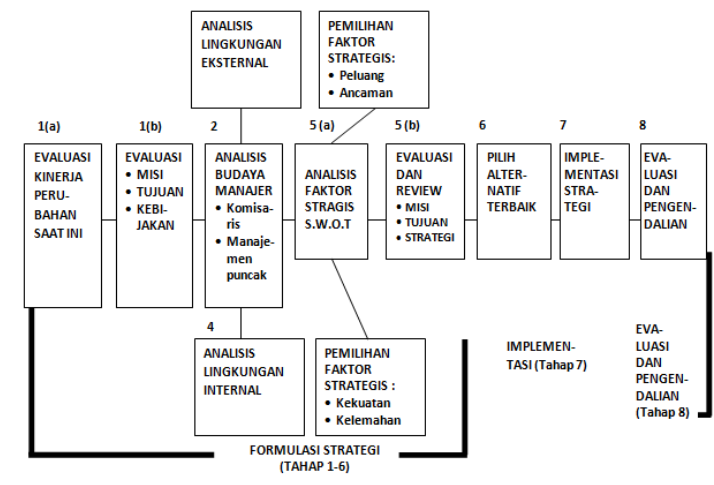

\section{Gambar 2 Kerangka Pemikiran}

(Sumber: Rangkuti,2009:18)

Analisis ini didasarkan pada logika yang dapat memaksimalkan kekuatan (Strength) dan peluang (Opportunity), namun secara bersamaan 
dapat meminimalkan kelemahan (Weakness) dan ancaman (Threat). Proses pengambilan keputusan strategis selalu berkaitan dengan pembagunan misi, tujuan, strategi, dan kebijakan perusahaan.

Dengan demikian perencanaan strategi harus menganalisis faktor-faktor strategis perusahaan dalam kondisi yang ada saat init. Hal ini disebut dengan Analisis Situasi. Model yang paling popular untuk analisis situasi adalah Anilisis SWOT (Rangkuti,2009).

\section{METODE PENELITIAN}

\section{Desain Penelitian}

Pengumpulan data dalam penelitian ini dilakukan melalui metode penelitian kualitatif.

\section{Objek dan Ruang Lingkup Penelitian}

Objek penelitian merupakan sasaran untuk mendapatkan suatu data (Umar, 2015).Penelitian ini dilakukan di salah satu perusahaan dagang yang bergerak di bidang server pulsa yaitu CV. STAR PRATAMA yang beralamat di Komp. Ruko Fanindo.

\section{Informan/Subjek Penelitian}

CV. STAR PRATAMA yang dipimpin oleh satu orang Direktur Utama dan memiliki 6 orang karyawan. Peneliti akan memberikan pertanyaan kepada pimpinan perusahaan yang berhak mengisi dan menentukan bobot dari setiap indikator termasuk pimpinan sendiri.

\section{Jenis dan Sumber Data}

1. Jenis Data

a. Data primer yaitu data yang diperoleh secara langsung oleh peneliti, berupa hasil wawancara dan hasil observasi yang dilakukan oleh peneliti.

b. Data sekunder yaitu data yang telah dikumpulkan untuk maksud selain menyelesaikan masalah yang sedang dihadapi. Data ini dapat ditemukan dengan cepat. Dalam penelitian ini yang menjadi sumber data sekunder adalah artikel, jurnal serta situs di internet yang berkenaan dengan penelitian yang dilakukan.

\section{Sumber data}

Untuk Menunjang penelitian ini penulis, maka diperlukan data yang sebagai berikut:

a. Gambaran umum perusahaan

b. Struktur organisasi

c. Proses bisnis perusahaan

d. Laporan keuangan perusahaan

e. Data lain yang berhubungan dengan penelitian

\section{Teknik Pengumpulan Data}

1. Wawancara, melakukan tanya jawab mendalam secara langsung dengan pihakpihak yang bersangkutan dengan penelitian dengan cara memberikan beberapa pertanyaan wawancara berupa data yang dibutuhkan untuk penelitian. Pada penelitian ini pihak-pihak tersebut adalah manajer dan karyawan perusahaan.

2. Observasi, Menurut (Satori, Djam'an dan Aan Komariah, 2012) pengamatan terhadap suatu objek yang diteliti baik secara langsung maupun tidak langsung untuk memperoleh data yang harus dikumpulkan dalam penelitian.

5. Dokumentasi, Teknik pengolahan data yang dilakukan dengan menaganalisis teks berupa dokumen terkait dengan proses pengiriman barang yang dilakukan setiap hari dan dokumen-dokumen pendukung lainnya yang berasal dari perusahaan maupun penelitianpenelitian terdahulu. Menurut Sugiyono (2013) dokumen merupakan catatan peristiwa yang sudah berlalu. Dokumen bisa berbentuk tulisan, gambar, atau karya-karya monumental dari seseorang.

\section{Analisis Lingkungan Internal}

Analisis terhadap faktor-faktor internal merupakan tahapan untuk mengetahui kekuatan dan kelemahan CV STAR PRATAMA. Analasis faktor internal ini dilakukan dengan pendekatan fungsional seperti sumber daya fisik, sumber daya manusia, keuangan, sumber daya teknologi, dan sumber daya manajemen. Dan dilakukan juga dengan pendekatan rantai nilai (value chain) seperti mulai dari aspek produksi, operasi, logistik, pemasaran, hingga layanan purna jual.

\section{Aspek Lingkungan}

a. Lokasi 
Rahmat \& Ricky, analisis swot sebagai dasar keputusan strategi pemasaran ....

Lokasi usaha ini terletak di Komplek Pertokoan Fanindo Blok F no.11 Kelurahan Tanjung Uncang, Kecamatan Batu aji. Lokasi CV STAR PRATAMA berada sangat strategis dan terjangkau.

Lokasi usaha ini sangat berdekatan dengan jalan raya, yaitu Jalan Brigjen Katamso sehingga sangat mudah dijangkau transportasi umum apalagi trasportasi pribadi. Letaknya yang dikelilingi pusat perbelajaan menjadikan CV STAR PRATAMA mudah diakses banyak orang. Lokasi usaha yang berdekatan dengan pasar, grosir, ATM, Bank, Hypermart, Sekolah, dan Fasilitas Umum lainnya menjadikan kekuatan bagi perusahaan dalam menjalankan bisnis server pulsa.

Kecamatan Batu aji sendiri memiliki jumlah penduduk nomor 3 terbanyak di Kota Batam setelah Kecamatan Batam Kota dan Kecamatan Sagulung. Dengan Penduduk kurang lebih 127 ribu jiwa, menjadikan kecamatan ini memiliki peluang yang bagus dalam berbisnis. Hal ini sesuai dengan peta penyebaran penduduk di kota batam sebagai berikut:

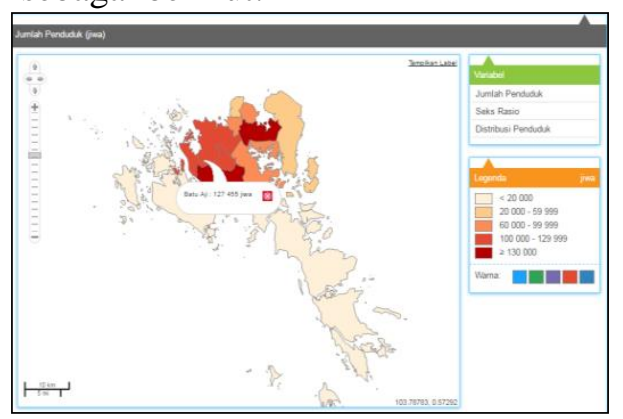

\section{Gambar 3 Peta Penyebaran Penduduk Kecamatan Batu Aji}

Sumber: http://sp2010.bps.go.id

b. Fasilitas

$$
\text { CV STAR PRATAMA }
$$
memiliki fasilitas untuk mendukung pelayanan kepada pelanggannya. Fasilitas tersebut seperti, ruang tunggu pelanggan, area parkir yang luas, dan toilet.

\section{Aspek Keuangan}

CV STAR PRATAMA memulai usaha ini dengan modal sendiri. Tetapi seiring berjalannya waktu, perusahaan mendapatkan pinjaman modal dari Bank Konvensional. Sehingga pinjaman tersebut dapat membantu perusahaan dalam mengembangkan bisnis menjadi lebih besar lagi.

Kondisi keuangan perusahaan terlihat cukup bagus. Hal ini disebabkan adanya peningkatan laba setiap tahunnya. Padahal penggunaan pulsa untuk SMS (Short Message Service) serta telepon menurun dan diiringi adanya peningkatan penggunaan media sosial dalam berkomunikasi, tidak membuat pendapatan perusahaan menurun. Pencatatan keuangan juga dilakukan perusahaan, pencatatan ini biasanya bersifat harian.

\section{Aspek Sumber Daya Manusia}

Sumber daya manusia menjadi fokus perusahaan dalam menjalankan bisnis server pulsa. Penggunaan perangkat server dan aplikasi komputer memerlukan keahlian dalam mengelolanya. Demi kelangsungan operasional, perusahaan memerlukan SDM yang mampu mengoperasikan perangkat server dan aplikasi komputer tersebut.

CV STAR PRATAMA memiliki 7 orang karyawan. Karyawan ini memiliki usia yang sangat produktif dari rentang 18 tahun hingga 21 tahun. Sehingga dengan usia tersebut, para karyawan baru akan lebih cepat menangkap ilmu yang diajarkan serta lebih inovatif dalam bekerja dan mampu menjadi pemecah masalah yang dihadapi oleh perusahaan.

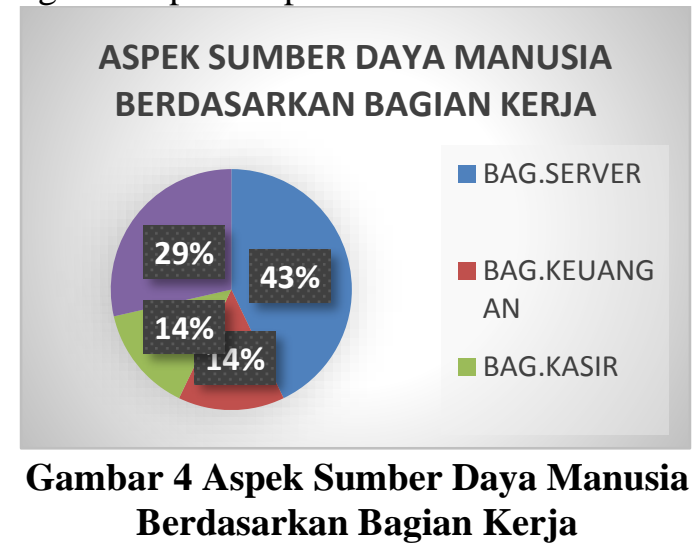




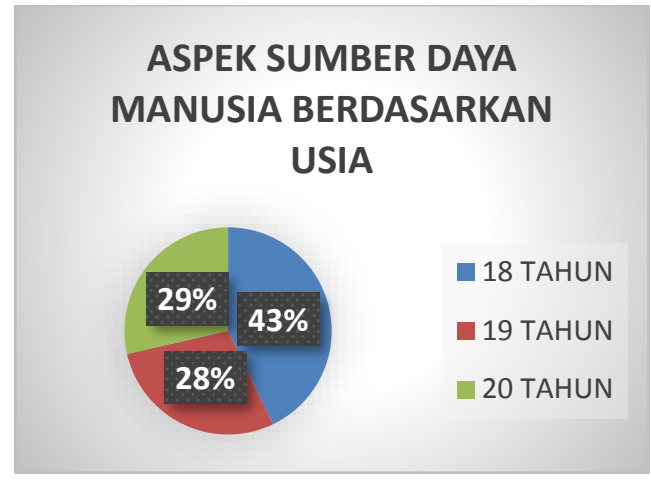

Gambar 5 Aspek Sumber Daya Manusia Berdasakan Usia

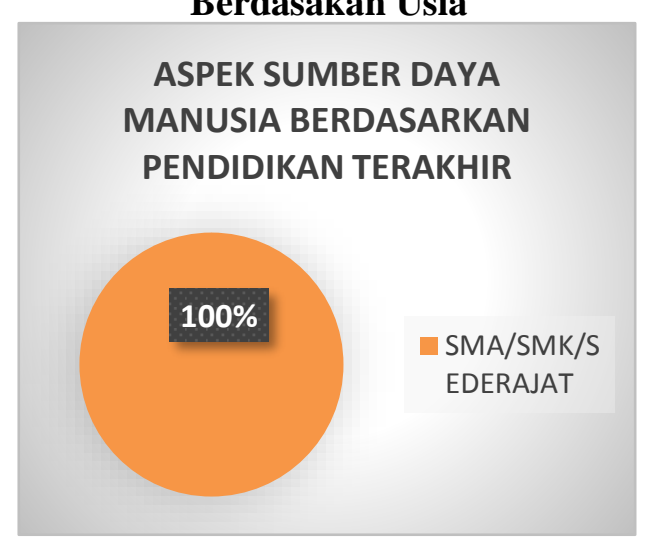

Gambar 6 Aspek SDM Berdasakan Pendidikan Terakhir

Dari segi kinerja, karyawan memiliki kinerja yang cukup baik. Perusahaan menerapkan rotasi pekerjaan sehingga karyawan dituntut untuk bisa ditempatkan diposisi manapun. Tetapi untuk standar kinerja, perusahaan belum memiliki standar kerja bagi karyawan.

\section{Aspek Operasional}

a. Produksi

Aspek produksi meliputi penggunaan teknologi, Struktur/ bagian kerja, kerusakana produk, serta Gangguan yang dihadapi. Berdasarkan hasil penelitian dapat disimpulkan bahwa (1) Perusahaan mengikuti perkembangan teknologi dengan melakukan upgrade perangkat server dan komputer, (2) Bagian kerja sudah jelas tetapi perusahaan masih belum mempunyai bagian IT tetap, sehingga apabila terjadi kerusakan perangkat harus memanggil teknisi dari luar, (3) Tidak ada kerusakan produk, karena produk yang dijual oleh CV Star Pratama adalah saldo pulsa yang bersifat tidak berwujud (intangible). Sehingga tidak ada produk yang rusak atau cacat. (4)
Gangguan yang dihadapi perusahaan lebih ke malfungsi perangkat yang digunakan seperti terserang virus, dilain sisi padamnya listrik akan menjadi gangguan dan ancaman serius bagi proses bisnis perusahaan.

b. Supply Chain

Meliputi Supplier dan hubungan dengan mitra. Berdasarkan hasil penelitian dapat disimpulkan bahwa (1) Jumlah Supplier sudah cukup yang terdiri dari 2 jenis pemasok yaitu, dealer (pemasok utama) dan sub dealer (pemasok kedua). (2) Hubungan dengan mitra sangat baik sekali. Mulai dari dengan supplier, agen/reseller, ataupun dengan perusahaan sejenis.

\section{c. Pelayanan Prima (Service Excellent)}

Perusahaan dalam melayani pelanggan cukup baik, dimana pelanggan yang akan membeli saldo pulsa dilayani dengan sepenuh hati sesuai dengan visi perusahaan. Ketika terjadi antrian pelanggan yang cukup banyak, pelanggan akan diminta dan menunggu di kursi/sofa yang telah disediakan. Ini merupakan bentuk pelayanan prima kepada pelanggan perusahaan.

\section{d. Layanan purna Jual (After Sales \\ Service)}

CV STAR PRATAMA juga memiliki layanan purna jual seperti penanganan komplain dari pelanggan. Biasanya komplain pelanggan ini melalui komunikasi telepon, lalu karyawan perusahaan akan mendengarkan keluhan dan memberikan solusi dari keluhan tersebut.

\section{Aspek Pemasaran}

Meliputi strategi promosi, eksistensi perusahaan, dan pelanggan tetap. Berdasarkan hasil penelitian dapat disimpulkan bahwa (1) strategi promosi yang dilakukan CV STAR PRATAMA yaitu dengan memberikan hadiah kepada agen yang beruntung, memberikan merchandise kalender, membuat iklan di Koran, hingga membuat iklan di internet. Tetapi perusahaan belum melakukan promosi via media sosial seperti facebook, instagram, dan lain-lain. (2) CV STAR PRATAMA sudah sangat eksis dikalangan agen pulsa di Batam. 
Rahmat \& Ricky, analisis swot sebagai dasar keputusan strategi pemasaran ....

\section{Analisis Lingkungan Eksternal}

Analisis terhadap faktor-faktor eksternal merupakan tahapan untuk mengetahui peluang dan ancaman CV STAR PRATAMA. Lingkungan analisis faktor eksternal ini meliputi aspek luar organisasi seperti Lingkungan Makro dan Lingkungan Industri.

\section{Lingkungan Makro}

a. Elemen Perekonomian

CV Star Pratama sangat memperhatikan sejauhmana perekonomian dapat mempengaruhi perusahaan dari mulai inflasi, kenaikan tarif dasar listrik \& air. Tapi hal yang paling mempengaruhi perusahaan ini adalah tentang tingginya tingkat pengangguran yang terjadi di Kota Batam.

b. Elemen lingkungan teknologi

Perubahan teknologi yang cepat memberikan dampak langsung kepada CV STAR PRATAMA. Perubahaan teknologi tersebut tidak hanya mencakup penemuan-penemuan yang baru saja, tetapi juga meliputi cara-cara pelaksanaanya atau metode-metode baru dalam mengerjakan suatu pekerjaan. Salah satu contoh perubahannya yaitu peningkatan penggunaan internet dan munculnya jaringan $4 \mathrm{G}$ di Kota Batam. Maka oleh dari itu, CV STAR PRATAMA harus siap dan menyeimbangi dari kemajuan teknologi tersebut.

2. Lingkungan Industri

a. Ancaman Pelaku Bisnis Baru

Semakin banyak munculnya bisnis server pulsa akan menjadi ancaman bagi CV Star Pratama sehingga perusahaan perlu membuat strategi khusus untuk terus dapat bersaing dan menjadi pilihan utama bagi pelanggan.

Apalagi munculnya server pulsa baru tersebut masih berdekatan lokasinya dengan CV STAR PRATAMA. Dengan munculnya perusahaan sejenis akan mengancam kelangsungan bisnis server pulsa perusahaan.

b. Kekuatan Tawar Menawar Pembeli Menurut Porter (2007), para pembeli biasanya akan membeli barang dengan harga termurah yang dapat diperolehnya. Untuk mengurangi biaya mereka, bisaanya pembeli meminta kualitas yang lebih tinggi, pelayanan yang lebih baik, serta yang terpenting adalah harga yang lebih murah. Dimana kita bisa melihat bahwa semakin besar pembelian, semakin banyak pilihan yang tersedia bagi pembeli dan pada umumnya akan membuat posisi pembeli semakin kuat. Munculnya penawaran yang dilakukan oleh pelanggan untuk menurunkan harga dan peningkatan kualitas pelayanan produk/jasa akan berdampak kepada strategi CV Star Pratama. Perusahaan harus cerdas dalam melihat situasi seperti, pembelian produk dalam jumlah besar, produk yang dibeli adalah produk standard dan tidak terdifferensiasi, dan pembeli yang mempunyai informasi yang lengkap.

Kekuatan Tawar Menawar
Pemasok
Pemasok akan memberikan harga dan kualitas pelayanan yang terbaik, CV Star Pratama harus mampu mencari banyak pemasok untuk mendapatkan harga yang terendah dan akan membuat perusahaan dapat bertahan serta dapat bersaing dikemudian hari.

\section{HASIL DAN PEMBAHASAN Matrik IFAS \& EFAS \\ 1. Matrik IFAS}

Dari tabel matrik IFAS dapat digambarkan bahwa CV STAR PRATAMA memiliki 8 kekuatan (Strength). Kekuatan terbesar dimulai dari (1) Lokasi Usaha Strategis (Mudah diakses oleh transportasi dan dekat dengan pusat perbelanjaan) yang memiliki rating paling tinggi yaitu 4 dan skor 0.44

(2) Sumberdaya Keuangan (Kondisi Keuangan, Pembiayaan Modal, Pencatatan, dan Peningkatan Keuntungan) memiliki rating 3 dan skor 0.3 , skor ini menjadikan kondisi keuangan menjadi kekuatan terbesar nomor 2 .

(3) Teknologi (Penggunaan dalam Operasional dan Produksi) memiliki rating 3 dan skor 0.21.

(4) Pelayanan Prima (Layanan langsung serta Layanan Purna Jual) memiliki rating 3 dan skor 0.15, (5) Eksistensi (Reputasi perusahaan, 
kepercayaan pelanggan, serta mempunyai pelanggan tetap) memiliki rating 3 dan skor 0.12 .

(6) Sumberdaya Manusia (SDM berusia Produktif, Kapabilitas, Pelatihan, Loyalitas, dan Jumlah SDM) memiliki rating 2 dan skor 0.12, (7) Sumberdaya fisik (Bentuk dan fasilitas pendukung) memiliki rating 2 dan skor 0.1 , (8) Strategi Promosi (Memiliki Strategi promosi yang menarik) memiliki rating 2 dan skor 0.04 , Hal ini didukung oleh pernyataan Bapak Yuli sebagai berikut:

Ada 4 faktor yang menjadi kelemahan perusahaan, mulai dari yang terbesar (1) Gangguan pada perangkat/peralatan dengan rating 1 dan skor 0.15 .

(2) Strategi pemasaran via media sosial dengan rating 2 dan skor 0.16 , lalu (3) Ada posisi/bagian kerja yang kosong (berdampak menurunnya produktifitas perusahaan) dengan rating 2 dan skor 0.16 , (4) Belum ada standar kerja karyawan (tolak ukur dalam penilaian kinerja karyawan) yang memiliki rating 3 dan skor 0.21, dan yang terakhir (5) Teknologi atau perangkat yang terbatas (Menghambat Operasional) memiliki rating 2 dan skor 0.24

\section{Matrik EFAS}

Dari table di atas dapat disimpulkan bahwa faktor peluang yang paling besar yaitu: (1) Peningkatan Penggunaan Paket data dan Internet dengan rating 4 dan skor 0.44

(2) Memiliki Banyak Pemasok (Pemasok utama dan pemasok cadangan) dengan rating 4 dan skor 0.28, (3) Menjalin hubungan baik dengan mitra (Hubungan dengan pemasok dan pelanggan) dengan rating 3 dan skor 0.27 .

(4) Perkembangan Teknologi (Penggunaan Smartphone dan sinyal 3G maupun 4G) dengan rating 3 dan skor 0.24 , (5) Banyak muncul perusahaan baru (berdampak pada daya beli masyarakat) dengan rating 2 dan skor $0.14,(6)$ Peningkatan wisatawan (berdampak peningkatan pendapatan) dengan rating 2 dan skor 0.1, (7) Pertambahan penduduk Kota Batam (terutama penduduk dekat lokasi usaha) dengan rating 2 dan skor 0.06 )

Adapun yang menjadi ancaman bagi perusahaan diurutkan dari yang terbesar yaitu:
(1) Listrik Padam (menimbulkan gangguan pada sinyal) dengan rating 1 dan skor 0.15 . Hal ini sesuai dengan hasil wawancara berikut:

(2) Munculnya bisnis server pulsa baru dengan rating 2 dan skor 0.16 , (3) Munculnya system Modern Channel dengan rating 2 dan skor 0.18, (4) Penurunan penggunaan SMS dan Telepon dengan rating 3 dan skor 0.24 , dan ancaman yang terkecil (5) Penggunaan kartu pasca-bayar dengan rating 3 dan skor 0.3 .

\section{Matrik Profil Kompetitif.}

Hasil matrik profil kompetitif pada CV

STAR PRATAMA sebagai berikut:

Tabel 1 Matrik Profil Kompetitif

\begin{tabular}{|c|c|c|c|c|c|c|c|}
\hline \multirow[b]{2}{*}{$\begin{array}{l}\text { FAKTOR } \\
\text { STRATEGI } \\
\text { S }\end{array}$} & \multirow[b]{2}{*}{$\begin{array}{l}\text { BO } \\
\text { BOT }\end{array}$} & \multicolumn{2}{|c|}{$\begin{array}{l}\text { CV } \\
\text { STAR } \\
\text { PRATA } \\
\text { MA }\end{array}$} & \multicolumn{2}{|c|}{$\begin{array}{l}\text { Central } \\
\text { Media } \\
\text { Reload } \\
\text { (CMR) }\end{array}$} & \multicolumn{2}{|c|}{ Hilmi Cell } \\
\hline & & $\begin{array}{l}\mathrm{R} \\
\mathrm{A} \\
\mathrm{T} \\
\mathrm{I} \\
\mathrm{N} \\
\mathrm{G}\end{array}$ & $\begin{array}{l}\text { BOB } \\
\text { OT }\end{array}$ & $\begin{array}{l}\mathrm{R} \\
\mathrm{A} \\
\mathrm{T} \\
\mathrm{I} \\
\mathrm{N} \\
\mathrm{G}\end{array}$ & $\begin{array}{l}\text { BOB } \\
\text { OT }\end{array}$ & $\begin{array}{l}\mathrm{R} \\
\mathrm{A} \\
\mathrm{TI} \\
\mathrm{N} \\
\mathrm{G}\end{array}$ & $\begin{array}{l}\text { BOB } \\
\text { OT }\end{array}$ \\
\hline $\begin{array}{l}\text { Lokasi } \\
\text { Usaha }\end{array}$ & 0.17 & 4 & 0.68 & 4 & 0.68 & 2 & 0.34 \\
\hline $\begin{array}{l}\text { Kualitas } \\
\text { SDM }\end{array}$ & 0.11 & 4 & 0.44 & 3 & 0.33 & 3 & 0.33 \\
\hline $\begin{array}{l}\text { Produksi } \\
\& \\
\text { Operasiona } \\
1\end{array}$ & 0.14 & 3 & 0.42 & 4 & 0.56 & 2 & 0.28 \\
\hline $\begin{array}{l}\text { Hubungan } \\
\text { Kemitraan }\end{array}$ & 0.14 & 4 & 0.56 & 3 & 0.42 & 3 & 0.42 \\
\hline Pemasaran & 0.16 & 3 & 0.48 & 3 & 0.48 & 2 & 0.32 \\
\hline Keuangan & 0.13 & 3 & 0.39 & 4 & 0.52 & 2 & 0.26 \\
\hline $\begin{array}{l}\text { Penggunaa } \\
\text { n } \\
\text { Teknologi }\end{array}$ & 0.15 & 3 & 0.45 & 3 & 0.45 & 2 & 0.3 \\
\hline Total & 1.00 & & 3.42 & & 3.44 & & 2.25 \\
\hline
\end{tabular}

Jika dilihat posisi CV STAR PRATAMA terletak di tengah-tengah dengan total skor 3.42 dibandingkan dengan pesaingnya yaitu Central Media Reload (CMR) dan Hilmi Cell. Perusahaan server pulsa Central Media Reload memiliki skor tertinggi dengan total skor 3.44 dan terakhir Hilmi Cell dengan total skor 1.82 .

\section{Matrik SWOT}

Berdasarkan matrik IFAS dan EFAS dapat diketahui bahwa faktor-faktor kekuatan 
Rahmat \& Ricky, analisis swot sebagai dasar keputusan strategi pemasaran ....

(Strengths) mempunyai nilai skor 1.48 sedangkan faktor-faktor kelemahan (Weaknesses) mempunyai nilai skor 0.92 . Berarti CV STAR PRATAMA mempunyai kekuatan yang lebih tinggi dibandingkan dengan faktor kelemahan dalam menentukan strategi bersaingnya. Selanjutnya faktor-faktor peluang (Opportunities) mempunyai skor 1,53 dan faktor-faktor ancaman (Threats) mempunyai nilai skor 1,03 , ini berati dalam upaya menentukan strategi bersaingnya $\mathrm{CV}$ :

STAR PRATAMA mempunyai peluang yang cukup besar dibandingkan ancaman yang akan timbul. Dari hasil susunan faktor-faktor internal dan eksternal diatas, menghasilkan rangkaian skor sebagai berikut:

1. Kekuatan (Strenghts/S) $=1.48$

2. Kelemahan $($ Weaknesses $/ \mathrm{W})=0.92$

3. Peluang (Opportunities/O)

4. Ancaman (Threats/T) $=1.03$

Dari rangkaian nilai skor tersebut, dapat disusun suatu tabel rekap skor IFAS dan EFAS sebagai berikut:

Tabel 2 Rekap Skor IFAS dan EFAS

\begin{tabular}{|c|c|c|c|}
\hline $\begin{array}{c}\text { Skor } \\
\text { Internal }\end{array}$ & $\begin{array}{c}\text { Skor } \\
\text { Eksternal }\end{array}$ & Kuadran & Pilihan Strategi \\
\hline $\begin{array}{c}\mathrm{S}>\mathrm{W} \\
(+)\end{array}$ & $\mathrm{O}>\mathrm{T}(+)$ & & \\
$1.53>1.03$ & & \\
$\begin{array}{c}\text { Selisih : } \\
0.92\end{array}$ & I & GROWTH \\
$\begin{array}{c}\text { Selisih }: \\
+0.56\end{array}$ & & & \\
\hline $\begin{array}{c}\mathrm{S}>\mathrm{W} \\
(+)\end{array}$ & $\mathrm{O}<\mathrm{T}(-)$ & II & DIVERSIFICATION \\
\hline $\mathrm{S}<\mathrm{W}(-)$ & $\mathrm{O}>\mathrm{T}(+)$ & III & STABILITY \\
\hline $\mathrm{S}<\mathrm{W}(-)$ & $\mathrm{O}<\mathrm{T}(-)$ & IV & SURVIVAL \\
\hline
\end{tabular}

Setelah dilakuakan pembobotan makan akan dihasilan selisih dari faktor interal yaitu + 0.56 dan selisih pada faktor eksternal yaitu +0.50 . Setelah itu dapat dibuat diagram SWOT seperti di bawah berikut:

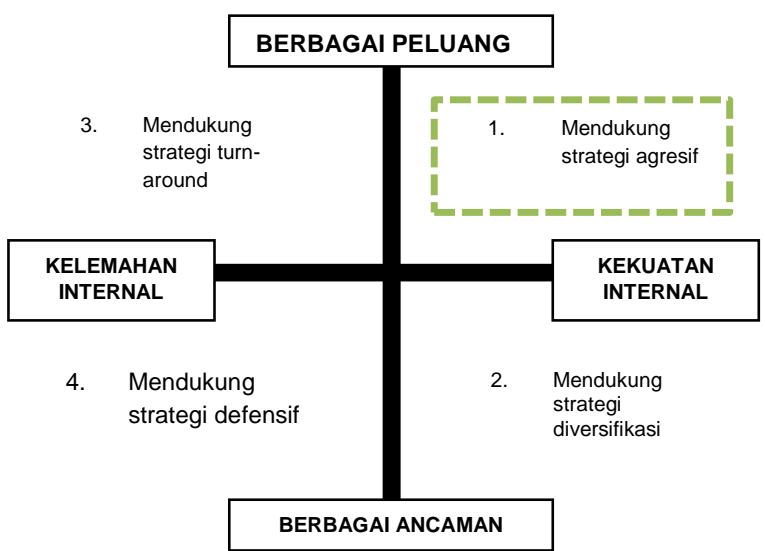

Gambar 7 Analisis SWOT

\section{Matrik IE (Internal Eksternal)}

Matrik IE digunakan untuk mengetahui posisi perusahaan berdasarkan hasil yang didapatkan dari matrik IFAS (2.4) dan EFAS (2.56)

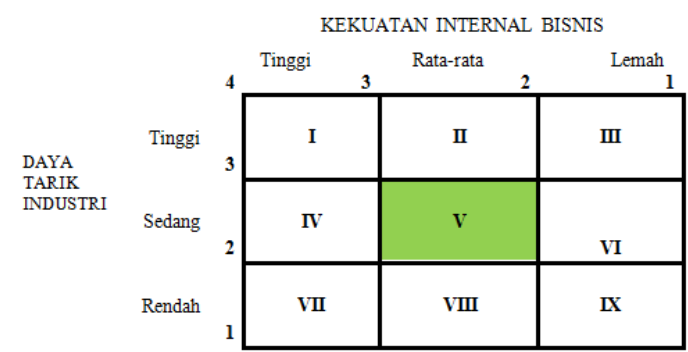

Gambar 8 Matrik IE

Hal ini dapat disimpulkan bahwa posisi CV STAR PRATAMA di sel V, yang berarti strategi yang dijalankan adalah strategi pertumbuhan dengan integrasi horizontal, yaitu dengan cara memperluas kegiatan lini produk atau membangun di lokasi lain yang tujuannya adalah meningkatkan jenis produk

\section{Matrik QSP}

Tabel 3 Matrik QSP

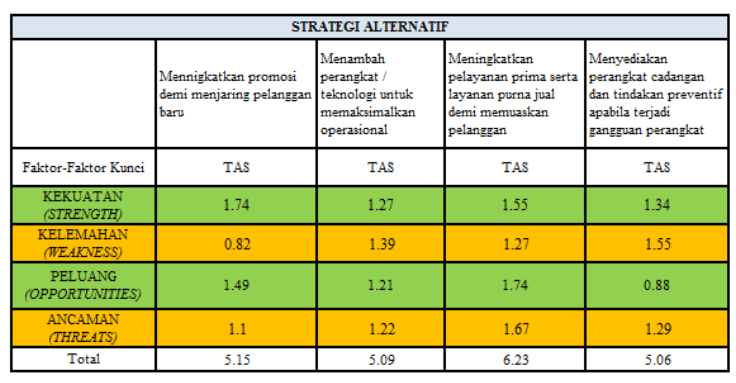

Berdasarkan hasil tabel QSPM, terdapat 4 strategi alternatif yang dapat dijalankan oleh perusahaan. Strategi yang paling besar yaitu (1) 
Meningkatkan pelayanan prima serta layanan purna jual demi memuaskan pelanggan dengan TAS (Total Attaractive Scores) 6.23, lalu yang terbesar nomor (2) Meningkatkan promosi demi menjaring pelanggan baru dengan total strategi alternatif dengan TAS sebesar 5.15, lalu yang ke (3) Menambah perangkat / teknologi untuk memaksimalkan operasional dengan TAS 5.09, dan terakhir yang paling kecil ialah (5) Menyediakan perangkat cadangan dan tindakan preventif apabila terjadi gangguan perangkat dengan TAS sebesar 5.06.

Berdasarkan hasil TAS masing-masing alternatif tersebut dapat disimpulkan bahwa strategi yang tepat untuk diaplikasikan CV STAR PRATAMA adalah strategi alternatif yang memiliki TAS paling besar. Strategi tersebut ialah Meningkatkan pelayanan prima serta layanan purna jual.

\section{SIMPULAN DAN SARAN \\ Simpulan}

Berdasarkan hasil penelitian yang telah dilakukan mengenai analisis SWOT sebagai dasar keputusan strategi pemasaran pada perusahaan server pulsa di Kota Batam maka dapat disimpulkan:

1. Faktor-faktor yang menjadi kekuatan CV STAR PRATAMA diurutkan dari terbesar hingga terendah yaitu, (1) Lokasi Usaha Strategis, (2) Sumberdaya Keuangan, (3) Teknologi (Penggunaan dalam Operasional dan Produksi), dst. Faktor yang menjadi kelemahan perusahaan diurutkan dari terbesar hingga terendah yaitu, (1) Gangguan pada perangkat/peralatan, (2) Strategi pemasaran via media social, (3) Ada posisi/bagian kerja yang kosong, dst.

2. Faktor-faktor yang menjadi peluang $\mathrm{CV}$ STAR PRATAMA diurutkan dari terbesar hingga terendah yaitu, (1) Peningkatan Penggunaan Paket data dan Internet, (2) MemilikiBanyak Pemasok (Pemasok utama dan pemasok cadangan), (3) Menjalin hubungan baik dengan mitra, dst. Adapun yang menjadi ancaman bagi perusahaan diurutkan dari yang terbesar yaitu:

Listrik Padam (menimbulkan gangguan pada sinyal), (2) Munculnya bisnis server pulsa baru, (3) Munculnya system Modern Channel,

3. Posisi bisnis server pulsa CV STAR PRATAMA dibandingkan dengan bisnis server pulsa lainnya dengan menggunakan matrik profil kompetitif berada pada posisi di tengah.

4. Berdasarkan diagram SWOT, CV STAR PRATAMA memiliki posisi pada kuadran I. Pada kuadran ini situasi perusahaan sangat menguntungkan. Strategi yang cocok diterapkan dalam kondisi ini adalah mendukung kebijakan pertumbuhan yang agresif. Berdasarkan Matrik IE (Matrik Internal-Eksternal) makan CV STAR PRATAMA berada pada sel V. Strategi yang diterapkan adalah pertumbuhan melalui kosentrasi melalui integrasi horizontal. Berdasarkan hasil analisis pada tahap keputusan menggunakan QSPM, dapat dilihat bahwa strategi yang terbaik yang harus dilakukan saat ini adalah salah satu strategi ST (Strength-Threat) yaitu dengan meningkatkan pelayanan prima serta layanan purna jual demi memuaskan pelanggan.

\section{Saran}

Berdasarkan pembahasan yang diperoleh dari penelitian ini, maka diajukan saran-saran sebagai pelengkap terhadap analisis SWOT sebagai dasar keputusan strategi pemasaran pada perusahaan server pulsa di Kota Batam adalah sebagai berikut:

1. Mengoptimalkan kekuatan yang dimiliki oleh perusahaan dan kelemahan yang dimiliki oleh perusahaan sebaiknya mulai diperbaiki.

2. Perusahaan juga harus memanfaatkan peluang yang ada untuk merebut pangsa pasar dan diharapkan mampu mencapai tujuan perusahaan. Selain itu ancaman yang ada tidak boleh dihiraukan, perusahaan harus memiliki tindakan preventif dalam menghadapi segala acaman yang muncul

3. Posisi perusahaan yang kuat dibandingkan dengan pesaingnya CMR dan Hilmi cell dalam hal kualitas SDM 
Rahmat \& Ricky, analisis swot sebagai dasar keputusan strategi pemasaran ....

dan hubungan kemitraan, sebaiknya menjadi motivasi perusahaan dalam meningkatkan pelayanan kepada pelanggan

4. Meningkatkan pelayanan prima serta layanan purna jual dapat dilakukan melalui penanganan cepat pada keluhan konsumen dan melayani dengan 5S (Senyum, Sapa, Salam, Sopan, Santun).

\section{DAFTAR PUSTAKA}

Anwar, M. C., \& Utami, M. C. (2012). Analisis SWOT pada Strategi Bisnis dalam Kompetisi Pasar ( Studi Kasus : Toko Pojok Madura). Jurnal Sistem Informasi, p-ISSN 1979-0767, 1-10.

David, R. F. (2009). Manajemen Strategi Konsep. Jakarta: Salemba empat.

Hening Widi Oetomo dan Lilis Ardini. (2009). Swot analysis in strategic management : a case study at Purbaya bus station. Journal of Economics, Business, and Accountancy Ventura ISSN 2087-3735.

Ilham. (2014). Jalur Distribusi Pulsa. Retrieved Januari 30, 2017, from vouchacare: https://support.voucha.co.id

Irawati, R, Syahroni, Benny. (2013). Analisis SWOT Pelabuhan Ferry International Sekupang, Batam. Jurnal Akuntansi, Ekonomi dan Manajemen Bisnis Vol. 1, No.1, 1-15.

Jimoh, R., \& Van Wyk, J. (2014). SWOT Analysis of Housing Co-operatives in South Africa. Civil Engineering Dimension, Vol.16, No 1 ISSN 14109530 print, 54-60.

Kotler, P. (2005). Manajemen Pemasaran. Jilid I. INDEKS, Jakarta.

Muhammad Firman, M. C. (2010). Asosiasi Server Pulsa Resmi Berdiri. Retrieved Januari 26, 2017, from viva.co.id: http://teknologi.news.viva.co.id

Oetom, H. W., \& Ardin, L. (2012). SWOT Analysis in Strategic Management: a case study at purabaya bus station. Journal of Economics, Business, and Accountancy Ventura.Vol 15, No 2, 171186.Porter, Michael E,Strategi Bersaing
(Competitif Strategy),Tanggerang: Karisma Publishing Group,2007

Rahayu, R. P., Rochmah, S., \& Ribiwanto, H. (2015). Strategi Pemerintah Daerah Dalam Mengembangkan Pariwisata Di Kabupaten Jombang. Jurnal Administrasi Publik (JAP). Vol. 3, No.1 , 122-127.

Ramadhan, A., \& Sofiyah, F. R. (2013). Analisis SWOT sebagai landasan dalam menentukan strategi pemasaran studi McDonald's Ring Road ). Jurnal Media Informasi Manajemen Vol 1, No 4, 1-10.

Rangkuti, F. (2001). Analisis SWOT teknik membedah kasus bisnis. Jakarta: PT.Gramedia Pustaka Utama.

Rangkuti, F. (2009). Analisis SWOT Teknik Membedah kasus Bisnis. Jakarta: PT Gramedia Pustaka Utama.

Satori, Djam'an dan Aan Komariah. (2012). Metodologi Penelitian Kualitatif. Bandung: Alfabeta.

Stefanus. (2010). Pengusaha Server Pulsa Bentuk Aspindo. Retrieved Januari 30, 2017, from Okezone: http://techno.okezone.com

Suhartini. (2012). Analisis SWOT dalam menentukan strategi pemasaran. Vol.XXI,No.3 ISSN 1693-6094.

Umar, H. (2001). Strategic Management In Action. Jakarta: Cetakan Kelima. PT Gramedia Pustaka Utama.

Yenida. (2012). Kajian analisis SWOT terhadap usaha industri kecil rotan Kota Padang. Polibisnis, Volume 4 No. ISSN 18583717, 1-16 